\title{
Designing the mechanism to measure the cost of living
}

\begin{abstract}
Consumer necessities can be determined objectively by scientific methods. Assessments of the consumer highlight subjective dimensions of the act of consumption that are as important as those goals because they are crucial in consumption practices and thus create a more realistic, complementary methods aims, the social perception of poverty.

Methods for calculating the subsistence minimum may be different; they are the subject of a rich scientific literature. The importance of poverty comes from its orientation on the one hand, the objectives of human necessities, and on the other hand, the actual economic situation. The latter refers to the nature of the supply of goods and services on the market, the relations between prices of goods and services and, not least, the proportions established between different incomes categories of the population. Particularly relevant are reporting the amount of poverty or of different amounts of minimum consumption basket - decent or subsistence, to the amount of income categories standard of the population, such as the guaranteed minimum income, minimum wage, minimum pension and average salary economy.
\end{abstract}

Volume 2 Issue 6 - 2018

\author{
Adina Mihăilescu \\ Research Institute for Quality of Life, Romania
}

Correspondence: Adina Mihăilescu, Senior Researcher Research Institute for Quality of Life, Romania, Email adina.mihailescu@yahoo.com

Received: October 17, 2018 | Published: December 20, 2018

Keywords: consumer, method, income, minimum, consumption, basket

\section{Introduction}

The Research Institute for Quality of Life permanent there were concerns social policy, poverty, income and consumption etc. Researchers from our institute using various methods and research tools, among them being and normative method, which helps to identify using thresholds of poverty, segments of the population in need and that they cannot help themselves but need State intervention through special measures of social protection. Normative method allows us to calculate values subsistence minimum for a decent life, and the minimum subsistence corresponding deprivation of a life which, in fact, identifies the poorest segments of the population. Scientific objective of the study is to seek the welfare/poverty and socio-human reflected in their degree of satisfaction of human needs. Difficult situations, even alarming, they live in some families, family of two adults with two dependent children, you have one average net salary and allowances of the two children, cannot cover the minimum decent life, then couple retired there one average pension insurance is also in difficulty, families in which one parent become unemployed or pensioners with minimum pensions offices are some examples of people identified as needing support and social protection and who live in poverty or at risk of falling into poverty, if not supported social distancing them from a decent life.

Depending on the socio-economic changes occurring, the change in prices for goods and services on the market, changing consumer mentality of the population, the minimum acceptable standard of living, and the sustenance that is good to be evaluated. Once established their value, they are updated monthly, inflation calculated and disseminated by the National Institute of Statistics. Usually full recalculation of the two minima is about three years to five years after emerging dynamic economic and social phenomena. Determination by calculating the subsistence minimum is an indispensable tool in analyzing the situation of the various stages of socio-economic development, which enables comparisons over time. Meeting consumption needs is a necessity for everyone as an individual, so for himself, but also for his family. When the individual cannot fight alone, he should be given protection appropriate institutions. Household income in Romania is characterized by relatively low wage contribution that provides only around half of total revenues. Most of the population's income is used to cover basic needs, food consumption expenses as a share exceeding $40 \%$ of total consumer spending - compared to $10-12 \%$ in Western countries. About half of Romanian households cannot meet the mandatory consumer spending compared to income they have. This in itself increases their vulnerability to risk losing or diminishing revenues.

Consumer necessities can be determined objectively by scientific methods. Assessments of the consumer highlight subjective dimensions of the act of consumption that are as important as those goals because they are crucial in consumption practices and thus create a more realistic, complementary methods aims, the social perception of poverty. Methods for calculating the subsistence minimum may be different; they are the subject of a rich scientific literature. The importance of poverty comes from its orientation on the one hand, the objectives of human necessities, and on the other hand, the actual economic situation. The latter refers to the nature of the supply of goods and services on the market, the relations between prices of goods and services and, not least, the proportions established between different incomes categories of the population. Particularly relevant are reporting the amount of poverty or of different amounts of minimum consumption basket - decent or subsistence, to the amount of income categories standard of the population, such as the guaranteed minimum income, minimum wage, minimum pension and average salary economy. Also relevant are reports from different categories of revenue improved to various social benefits such as child benefit etc. or reports to other categories of social benefits such as unemployment compensation or allowance minimal support. Quality of Life Research Institute calculated since its inception a number of assessment tools welfare of the population of Romania, as the value of the minimum consumption level of survival or at least decent for different categories of households. ${ }^{1-4}$ In what follows, we will also 
present a series of evaluations of social welfare of the population in Romania, particularly relevant in creating an image, even very approximate, on the general and psychological balance of the majority population.

Family types examined in the residential profile:

\section{In urban areas:}

i. Family of employees with two dependent children

ii. Family of two pensioners

\section{In rural areas:}

i. Family of two farmers, active, with two dependent children

ii. Family of two elderly, inactive, former farmers, self-employed or former employees of the earth into state structures

These options represent the most common types of families in our country.

The values of the two types of consumer baskets are given in the following, for the month of September 2016 (see Annex):

Employees with two dependent children-4 people, urban, September 2016

a) decent 2,273 lei

b) subsistence 1,842 lei

Farmers with two dependent children-4 people, rural, September 2016

a) decent 1,831 lei

b) subsistence 1,600 lei

\section{Presentation tool: a minimum basket of living}

In everyday life a person needs for shelter, food, clothing, footwear, medicines, in order to maintain a good shape as physical and mental. But it must not overlook another important aspect and one that a human being is integrated in society, and for this it needs information (press, TV, papers, etc.) while remaining open after hours coverage with work. Each person or family consumption is directly linked not only to the material sphere, but also of the spiritual, not insignificant. Of course that consumption is closely related to several factors: income, profession, place of origin, traditions, habits, level of training, education, health, etc, social-economic processes and economic development achieved by the country in question..$^{5-8}$

Minimum basket corresponding to a decent standard of living includes resource requirements for current consumption: food, clothing, footwear, housing, services in minimal quantities and purchase prices of goods and services also minimal, plus the costs of education and training professional favors affirmation of individual and social status (cultural services, postal services and telecommunications) to enable individual development and participation in society and his family. Decent minimum basket calculated at the Institute for Quality of Life Research covers expenditure for the following types of families:

a) Two persons with two dependent children in urban areas

b) Two active farmers with two dependent children in rural areas

Food consumption was based on consumption norms set by nutritionists' specialists from the Institute of Hygiene and Public Health in Bucharest. These norms of consumption for an adult and active professional working in conditions of physical and intellectual environments fall between 2,700 and 3,200 calories a day. In our research we were chosen to define subsistence minimum, with food consumption need 2,700 calories per day, the minimum set by nutritionists. All amounts are based on adult consumption active. To determine the monthly consumption to a family of adult children take into account your favorite food items, and recommended by specialists, man, woman, and child (ren). Using the equivalence scale for consumption or value 1 for the head of household, husband, employee, 0.9-to woman, employed, 0.7-for the first child in the household and 0.5 - for the second child in our household it led a total value of 3.1 .

The products were recorded as necessary: meat and meat derivatives. Another group dairy products and milk derivatives settled everything according to your preferences and how they are healthy for the body. In further particular group has been necessary oil fat in daily food preparation, as well as vegetables which come to complete the nutrient components necessary for the optimal functioning of the human body. The next option families in need of food, potatoes consumed in large quantities in our country and which is found in all cultures, plain and hill plateaus in the south as in the north, west and east of the country that; Beans also a vegetable common in our country and in winter as in summer, dry or green, depending on the season; apples from the fruit that also have the widest range states in the country and found in all seasons, while being highly nutritious human body. Were added to sugar and sweets in small quantity, coffee mentioned in consumer habits and preferences of adults in our country.

A separate analysis is to evaluate self-consumption in rural areas. Revenues from self-consumption accounted for $16 \%$ of total household income. Calculation of minimum standard of living by normative method, in rural areas, self-consumption is estimated at $38.6 \%$.

i. Of the products that are purchased in urban and rural areas are consumed within the household, mention: the milk of cows, sheep and cow cottage cheese, yogurt, butter, regarding dairy, and other products that are prepared from milk; pork, beef and chicken, lard and eggs originating from animals and birds raised in their households; of the root vegetables were considered carrots, onions, garlic, greens, potatoes, green beans and dry as obtained throughout the years by those peasant families.

ii. In another chapter of expenditure clothes, footwear account was taken primarily on the sex of the person for which the calculation is made and season. This was the reason of detailing products for man -socially active, man-inactive retired woman-socially active woman-disabled, pensioner, child-school boy, child-school girl, for each case, taking into account those required in Chapter clothing/footwear in the house and outside living space.

iii. Housing Reference is made up of 3 rooms for employees or farmers with children and 1 room (studio) family of older, urban and rural. Other expenses related to housing, electrical items and household goods, sanitary ware and hygiene textiles for household use, tableware, cutlery, glassware and other household products, and expenses related to cultural services, personal care services repair and maintenance of clothing and footwear were properly set for four people, urban, rural and two elderly, urban and rural.

iv. Transport envisages 2 monthly fees, a means of transport, if urban employees who travel daily to work, children need not, considering that attend schools close to home; Four trips to class II by train employees for family with children once a year, when moving annual leave; 2 trips discount equal a whole travel by train for family pensioners (elderly) in urban and rural areas when moving, once a year, annual leave and treatment.

v. School supplies and other stationery relate, in particular, children's school requirements, but also a necessary minimum for adults. 
vi. Drugs retain only those strictly necessary for first aid kit rather lengthy treatment, namely to follow, starting from the premise healthy aging, population and no cases where treatments long periods of time.

vii. In calculating the minimum decent living for all families analyzed: employees with two children, urban and rural foreseen an amount of $10 \%$ of the final consumer basket for a fund safety and economy in order cover miscellaneous expenses required contingency of joy

Table I Minimum living standard basket during 1990-2016

\begin{tabular}{|c|c|c|c|c|c|c|c|}
\hline \multirow{2}{*}{$\begin{array}{l}\text { Month } \\
\text { Years /Families }\end{array}$} & \multicolumn{6}{|c|}{ October } & \multirow{2}{*}{$\begin{array}{l}\text { September } \\
2016\end{array}$} \\
\hline & 1990 & 1995 & 2000 & 2005 & 2010 & 2015 & \\
\hline \multicolumn{8}{|l|}{ Active persons in urban } \\
\hline One employee & $\mathrm{I} .778$ & I79.248 & 2.214 .396 & 474 & 666 & 739 & 735 \\
\hline Family with two employees & 3.378 & 340.572 & 4.207 .352 & 900 & 1.265 & 1.403 & 1.395 \\
\hline Family with two employees and one dependent child & 4.623 & 466.046 & 5.757 .429 & 1.232 & I.73। & 1.92 & 1.908 \\
\hline Family with two employees and two dependent children & 5.512 & 555.67 & 6.864 .627 & 1.469 & 2.064 & 2.287 & 2.273 \\
\hline \multicolumn{8}{|l|}{ Active persons in rural } \\
\hline One farmer & 1.579 & 159.387 & 1.973 .344 & 409 & 536 & 594 & 591 \\
\hline Family with two farmers & 3 & 302.835 & 3.749 .354 & 778 & 1.018 & 1.13 & 1.124 \\
\hline Family with two farmers and one dependent child & 4.105 & 414.405 & 5.130 .694 & 1.065 & 1.394 & 1.548 & 1.539 \\
\hline Family with two farmers and two dependent children & 4.895 & 494.099 & 6.117 .367 & 1.27 & 1.662 & 1.843 & 1.831 \\
\hline
\end{tabular}

Source: calculations by the author based on monthly inflation rates disseminated by the NIS
Minimum consumer basket calculated by normative method in relation to the basket RIQL and inductive set by the National Institute of statistics, the survey on household budgets categories

In the following we will make an analysis of the structure of total consumption expenditure to cover the chimney minimum living standard, the families of two persons with two dependent children and compare these costs with those of families with head of household employee submitted data NIS, in the two areas (urban and rural), Table 2.

Table 2 Structure of total consumption expenditure for decent minimum basket, the families of employees and farmers and comparison with the NIS data in May 2014 (\%)

\begin{tabular}{|c|c|c|c|c|}
\hline \multirow[t]{2}{*}{$\begin{array}{l}\text { Total expenses consumer } \\
2014\end{array}$} & \multicolumn{2}{|c|}{$\begin{array}{l}\text { Family with } 2 \text { employees and } 2 \text { dependent } \\
\text { children (RIQL)/ Family with employee head of } \\
\text { household (NIS) }\end{array}$} & \multicolumn{2}{|c|}{$\begin{array}{l}\text { Family with } 2 \text { farmers and } 2 \text { dependent } \\
\text { children (RIQL)/ Family with farmer head of } \\
\text { household (NIS) }\end{array}$} \\
\hline & RIQL- DMB & NIS & RIQL- DMB & NIS \\
\hline I. foods and drinks & 46,1 & 44,1 & $4 I, 5$ & 61,7 \\
\hline 2. clothing, footwear & 6,0 & 6,3 & 10,8 & 5,5 \\
\hline $\begin{array}{l}\text { 3. housing, water, electricity, gas } \\
\text { and other fuels }\end{array}$ & 13,1 & 16,6 & 13,5 & 12,2 \\
\hline 4. furniture, housing facilities & 3,1 & 3,8 & 7,9 & 4,0 \\
\hline 5. health & 5,7 & 2,7 & 1,9 & $\mathrm{I}, 8$ \\
\hline 6. transportation & 7,1 & 8,2 & 4,5 & 4,8 \\
\hline 7. post and telecommunications & 0,9 & 5,5 & 3,6 & 3,3 \\
\hline $\begin{array}{l}\text { 8. education, recreation and } \\
\text { culture }\end{array}$ & 2,3 & 6,3 & 3,0 & 3,4 \\
\hline
\end{tabular}

\section{This data reflects:}

Data analysis, which compares the structure of the consumer basket calculated by normative method (RIQL) for dual earner family with two dependent children, adults and equivalent to 3.1 monthly average consumption (NIS recorded by Households Survey) the same month and the same type of family, adult equivalent of 2.8 reflects that decent minimum value was 2,277 lei compared to the average monthly consumption 2,078.5 lei, the level of October 2014, $91.3 \%$ represent the value of the basket calculated by NIS, the value calculated standardized basket RIQL. (wedding, christening) or trouble (illness, hospitalization, death) arising in people's lives.

In the following we will focus on some types of family nuclei in our country, which have some relevance in the overall population of Romania, after which we will present expenses and income of these families active in urban and rural areas.

Here's the total consumption expenditure to cover minimum living standard basket during 1990 - 2016 (Table 1): 
Table Continued...

\begin{tabular}{|c|c|c|c|c|}
\hline \multirow[t]{2}{*}{$\begin{array}{l}\text { Total expenses consumer } \\
2014\end{array}$} & \multicolumn{2}{|c|}{$\begin{array}{l}\text { Family with } 2 \text { employees and } 2 \text { dependent } \\
\text { children (RIQL)/ Family with employee head of } \\
\text { household (NIS) }\end{array}$} & \multicolumn{2}{|c|}{$\begin{array}{l}\text { Family with } 2 \text { farmers and } 2 \text { dependent } \\
\text { children (RIQL)/ Family with farmer head of } \\
\text { household (NIS) }\end{array}$} \\
\hline & RIQL- DMB & NIS & RIQL- DMB & NIS \\
\hline 10. hotels, cafes, restaurants & - & 1,9 & - & $\mathrm{I}, \mathrm{I}$ \\
\hline II. safety and savings fund & 10,0 & - & 10,0 & - \\
\hline Total value October 2014 & 2.277 & 2078,5 & $\mathrm{I} .834$ & $13 \mid 2,5$ \\
\hline
\end{tabular}

Source: Coordonate ale nivelului de trai înRomânia, “Nivelul cheltuielilor totale de consum, pe destinații și categorii de gospodării, după statutul ocupațional al capului gospodăriei, în anul 20I4”, INS, București, 20I5, Tabelul 3.6./pg.59

Legend: DMB, Decent Minimum Basket; RIQL, Research Institute for Quality of Life; NIS, National Institute for Statistics.

For rural family of two active farmers with two dependent children have a consumer basket of 1,834 lei, calculated normative method (RIQL) while the average monthly consumption value farming families (Survey of October NIS) was 1,312.5 lei; 71.6\% represent value calculated by NIS basket of basket value calculated RIQL.

i. The normative method (RIQL), consumption is regulated by Nutritionists as individuals and their families should consume to be healthy in relation to exercise, mentally and intellectually held by employees and children, while the average monthly consumption (NIS) reflects what people spend, sometimes without respecting the rules of hygiene and nutrition; Consumption employees as he said the population is more staggered than would be through standardization, representing about $91 \%$ of the set by nutritionists;

ii. Farming families with dependent children per family would need an additional $30 \%$ (one third) of what is required at a minimum decent compared to what currently consumes and was recorded by NIS.

\section{Conclusion on the comparison with consumer basket RIQL and NIS}

a. Normative method (RIQL), consumption is regulated by nutritional experts as individuals and their families should consume to be healthy in relation to exercise, mentally and intellectually held by employees and children, while the average consumption monthly (NIS) reflects what people spend, sometimes without respecting the rules of nutrition and hygiene.

b. Consumption employees as he said the population is more staggered than would be through standardization, representing about $91 \%$ of the set by nutritionists.

c. Farming families with dependent children per family would need an additional $30 \%$ (one third) of what is required at a minimum decent compared to what currently consumes and was recorded by NIS.

\section{Acknowledgments}

None.

\section{Conflicts of interest}

Author declares that there is none of the conflicts.

\section{References}

1. Mărginean Ioan, Ana Bălaşa. Calitatea vieţii în România. Editura Expert, Bucureşti, 2002.

2. Mihăilescu Adina. Minimul de trai și costurile sociale concepte operaționale în analiza calităţii vieţii. 2004.

3. Mihăilescu Adina. Coşul de consum al populaţiei României, Bucureşti: Expert. 2012.

4. Mihăilescu Adina. Minimul de trai instrument în politicile sociale, București: Editura Academiei Române. 2014

5. Anuarul Statistic al României. INS, Bucureşti, 2015, Tabelul. $2014 ; 170-171$.

6. INS. Coordonate ale nivelului de trai în România. "Nivelul cheltuielilor totale de consum, pe destinaţii şi categorii de gospodării, după statutul ocupaţional al capului gospodăriei, în aanul 2014”. Bucureşti. 2015.59 p.

7. Stanciu Mariana, Adina Mihăilescu. Starea sărăciei din România în context european. Raportul social al ICCV, Bucureşti. 2011.

8. Ştefănescu MV. Social Research: Theory and Practice. In: Stanciu M, Mihăilescu A, editors. Vulnerable group of children and families with children in Romania. 2015. 413 p. 